\title{
Subcontracting, facilitating and qualities of regional power: the UK's partial pivot to Asia
}

\author{
Oliver Turner ${ }^{1}$ (D)
}

Received: 17 January 2018 / Revised: 23 July 2018 / Accepted: 28 October 2018 /

Published online: 10 November 2018

(C) The Author(s) 2018

\begin{abstract}
This article explores the UK's foreign policy "pivot" to Asia, a decade after its tentative beginnings. This pivot is understood to be Britain's planned redirection of attention and resources to Asia which emerged gradually from around 2007/2008, before intensifying from 2010. It is argued that the pivot has been evident across distinctive phases and political, economic and security dimensions, while lacking organisation, clarity and purpose, leaving it partial and incomplete. Examined are the motivations for the pivot and the forms it has taken, its accomplishments and ultimately what the pivot reveals about the role and influence the UK claims in Asia today. It is shown that in its key trade and investment aims, the pivot has achieved mixed results, doing little to enhance the UK's position as a tertiary-level partner of Asia. However, Britain's agency and importance is best explained not by its quantities, but its qualities, of power, occupying the regional roles of "subcontractor" and "facilitator". Finally, the article looks to Britain's future in Asia. Exiting the EU would likely see the UK retain its status of subcontractor, while its ability to act as facilitator would almost certainly diminish. The article concludes by arguing that, despite the rhetoric of the pivot, Britain's presence in Asia will never be defined by its quantities of material power, and that it should work to sustain the qualities of power on which its regional presence is built.
\end{abstract}

\section{Introduction}

The impacts of the economic and financial crash of 2007/2008 brought about policy reorientations in the UK and wider West. Fiscal and monetary projects at home, including quantitative easing and budget austerity, were coupled with reassessments of foreign policy abroad. A wealth of scholarly attention centres upon the USA's "pivot" (later the "rebalance") to Asia under the Obama administration, designed to reassert American

Oliver Turner

oliver.turner@ed.ac.uk

1 Department of Politics and International Relations, University of Edinburgh, 3.02 Chrystal Macmillan Building, 15A George Square, Edinburgh EH8 9LD, UK 
authority in a region of increasing strategic significance at a time of shifting distributions of global power (for example Tow and Stewart 2015; Bisley and Phillips 2013; Jennings 2013). Yet the UK, alongside other European nations, embarked upon a "pivot" of its own.

In August 2013, French Foreign Minister Laurent Fabius asserted that France "has undertaken a 'pivot' to Asia" (Embassy of France in London 2013). Germany (Sharief 2013), the Netherlands (Netherlands Government 2016) and others have expressed similar aims. ${ }^{1}$ These Western pivots were always largely independent of one another, and disparate in nature and scope. European strategies have been less security-focussed than that of the USA. Especially for the UK and France, they have also been driven by post-colonial ambitions to recover a lost presence in Asia, while the USA sought to reassert a regional omnipresence which never reached a discernible end. In April 2012, former UK Foreign Secretary William Hague announced that "[t]oday, Britain is looking East as never before. We are setting our country firmly on the path to far closer ties with countries across Asia" (FCO 2012).

This article examines the UK's foreign policy "pivot" to the region. This pivot has neither been explicated in detail by UK governments nor organised into a single or entirely coherent policy programme. However, its strategy boasts physical structures and contours now manifest for around a decade, which speak directly to questions about Britain's place in, and importance to, Asia today. Whitehall has done much to signal that Asia is key to Britain's future global prosperity, while insisting that the UK remains an important element of Asian affairs and redirecting foreign policy resources in that direction. This "pivot" to Asia is outlined elsewhere (see Warren 2014; Blount 2013), including within the context of European approaches to the region (Simón and Klose 2016). While existing analyses are stronger on the physical contours of the pivot, however, they tell us little about what it has achieved and, ultimately, about the particular space the UK occupies in modern day Asian affairs.

Pertinent questions therefore remain. Why do Asian actors pursue enhanced diplomatic, economic and security arrangements with a physically limited and geographically detached UK, and why do they work to integrate the UK into their institutional architectures? Ultimately, what are the particular forms of power and influence Britain claims in twenty-first century Asia? What difference, if any, has its attempted "pivot" to the region made in these regards? This article examines the motivations for the UK's pivot to Asia and its manifestations to date, what the pivot has achieved and what it reveals about the UK's presence in Asia a decade after its tentative emergence in the aftermath of $2007 / 2008$, as the country prepares for a new chapter of internationalism outside the European Union. The focus is the post-2010 period and UK engagement with key partners in East and South East Asia, as well as notable others such as India.

The first section interrogates the political, economic and security dimensions of the pivot which is divided into three main phases since 2007/2008. It is argued that the pivotconfidently but incompletely set out in a small number of policy statements - has been idealistic and rife with internal contradiction. Despite ambitions for expanded regional involvement, self-imposed limitations on UK foreign services and a lack of long-term vision have resulted in a partial and disjointed shift of attention and resources.

The second section explores the achievements of this partial pivot and what its developments say about the UK's contemporary role in Asia. Drawing from data

\footnotetext{
${ }^{1}$ On the EU's "pivot" to Asia, see Sverdrup-Thygeson (2017).
} 
obtained from the UK Office for National Statistics and interviews with diplomats to the UK of East and South East Asia and with staff of British non-governmental organisations, it is shown that the pivot has done little to improve the UK's standing as a tertiary-level partner of Asia. Attention then shifts from a concentration on quantities of (economic and military) state power to qualities of power. The latter are shown to have been central to the UK's post-2010 pivot and its regional function in broader terms, with Britain now occupying two primary roles in Asia: those of "subcontractor" and "facilitator".

The final section looks to the UK's future in Asia as it plans to exit the EU. It is argued that while the UK would likely remain a specialist regional subcontractor, post2016 uncertainties around its future direction and international relationships mean its prized status as facilitator risks becoming diminished.

\section{What, why and how? The UK's partial pivot to Asia}

In 2008, the Labour government established the UK-China Economic and Financial Dialogue and a reallocation of Foreign and Commonwealth Office (FCO) resources towards Asia began, albeit with a lingering focus on Afghanistan and South Asia as theatres of the War on Terror (Foreign Affairs Committee 2009, 32). With the change to a (Conservative-Liberal Democrat) coalition government in 2010, the pivot advanced into a newly intensified second phase. The National Security Council (NSC) and its Sub-Committee on Emerging Powers were established, with its concentration soon narrowing upon Asia where growth remained comparatively strong and consistent. In 2012, William Hague noted that "[o]f the 29 countries we have identified for these efforts, 11 are in Asia, and we have put the need to turbo-charge our economic and political ties with them among the very top priorities" (FCO 2012). National "soft power" initiatives like the GREAT campaign targeted Asian markets (Pamment 2014).

A network shift at the FCO saw diplomatic operations withdrawn from Europe and expanded in China, India, Thailand, Myanmar, North and South Korea, Mongolia and Vietnam, among others (FCO 2011). This refocussing of international priorities complemented what some describe as the UK's return to the "East of Suez", in pursuit of closer relations with Gulf and Indo-Pacific partners (Vasager 2016). Enhanced interest in Asia stemmed largely from the (post-2010) coalition, then (post-2015) Conservative, governments' aims of reducing the national deficit via an increasingly mercantilist foreign policy (HM Treasury 2010) and has always been framed principally in economic, as well as diplomatic, terms. The NSC's Emerging Powers Sub-Committee was "heavily prosperity focussed" (House of Commons Defence Committee 2011, 29), and government targets included doubling trade with China, Indonesia and Malaysia (Department for Business, Innovation and Skills 2012; Cabinet Office 2012a, 2012b).

From 2010, the pivot quickly centred around ambitions for intensified trade and investment with China. British delegations made high profile visits in 2010 and 2013, with Chinese delegations visiting the UK in 2011 and 2014. In 2015, \$50bn of trade and investment deals and a UK-China Infrastructure Alliance were announced (Department for International Trade 2016). The UK became the first Western economy to issue a Chinese currency bond and the first major Western economy to join the Chinese-led Asian Infrastructure Investment Bank (AIIB). Membership was driven by 
the Treasury in its pursuit of closer economic relations with Beijing and with the aim of London becoming central to trade in the Chinese yuan (Casarini 2015).

This "golden era" of UK-China relations however, in which the former sought to become the latter's "best partner in the West" (HM Treasury 2015), attracted hyperbole, driven by the centuries-old myth of the China market which has always been less an external reality than a fantasised Western construct (see Turner 2014). Former prime minister David Cameron was warned by Beijing against "finger pointing" over China's human rights record (Wintour 2011), and UK-China diplomacy suffered following a 2012 meeting between Cameron and the spiritual leader of Tibet, the Dalai Lama; diplomatic visits were cancelled and Whitehall was forced to distance itself from the issue (Osborn 2013). Yet, products of this so-called golden era extended beyond the economic. The UK, for instance, now has more Confucius institutes and classrooms than anywhere outside the USA (Confucius Institute Headquarters 2014).

Elsewhere, and after becoming the first EU member to appoint an ambassador to the Association of South East Asian Nations (ASEAN) in 2009, the UK re-opened an embassy in Laos in 2012, gaining a diplomatic presence in each of the institution's national capitals. David Cameron's first overseas visit beyond Europe after the 2015 general election was a trade mission to South East Asia (Prime Minister's Office 2015). In India, two new Deputy High Commissions in Hyderabad and Chandigarh opened in 2012 (UK Government 2012), and in 2010 and 2013, high-profile UK trade delegations visited the country.

After decades of decline, the UK's military-security profile in Asia is modest. Its infantry garrison in Brunei survives (though primarily because its operating costs remain covered by the sultanate), along with a naval fuel depot and berthing wharves in Singapore. The UK also retains the British Indian Ocean Territory and is a founding member of the Five Power Defence Arrangements, the United Nations' Command Military Armistice Commission in Korea and the Five Eyes intelligence alliance. The UK attends meetings of the Asia Pacific Intelligence Chiefs and the Shangri La Dialogue security forum, as well as the biennial Rim of the Pacific Exercises. Prior to 2010, the UK thus maintained a formalised and codified, but generally low-cost and low-commitment, security presence in Asia, centred around partnership and dialogue forums. The UK's 2010 National Security Strategy (NSS) focussed far more on the Middle East and North Africa than Asia (UK Government 2010). Nevertheless, during the second phase of its pivot, the UK adopted a twin strategy of further integrating itself into regional security institutions, while formulating new bilateral arrangements.

In 2012, it joined South East Asia's Treaty of Amity and Cooperation, and the Regional Cooperation Agreement on Combating Piracy and Armed Robbery Against Ships in Asia (ReCAAP). In 2013, it signed a Defence Equipment Cooperation Framework and an Information Security Agreement with Japan, to improve joint mechanisms for sharing classified information (UK Government 2013). The 2015 NSS, which more comprehensively outlined the UK's approach to the region, described Japan as Britain's “closest security partner in Asia" (UK Government 2015, 57). In 2016, security arrangements with Japan were upgraded to a $2+2$ defence dialogue as London pledged to "play a more proactive and constructive role for the Asia-Pacific security environment" (Japanese Ministry of Foreign Affairs 2016a). In 2014, the UK also established an annual Ministerial Strategic Dialogue with South Korea (UK Government 2014).

In 2014, Beijing's Ambassador to London, Liu Xiaoming, indicated that the "golden era" in UK-China relations was overhyped and unsustainable, noting that Britain ranked 
behind Germany and France in Chinese estimations (Ford and Kynge 2017). Clearer signs that the pivot was transitioning into a third phase, in which China was no longer the fulcrum of Britain's Asian ambitions, became most apparent with the UK's referendum on EU membership and subsequent change of government leadership in June 2016.

A key pillar of the Leave EU campaign was the promise of economic opportunities beyond Europe, with India, Australia, ASEAN and the Commonwealth. Government rhetoric since the Brexit referendum has promoted this vision of a Global Britain which "get[s] out into the wider world, to trade and do business all around the globe" (Prime Minister's Office 2017), with less singular emphasis on China. The new British government, led by Theresa May, quickly established a High Level Security Dialogue with China (UK Government 2016). More recently, Chinese officials have complained of a lack of enthusiasm from the May government and chose not to repeat a large auction of renminbi bonds in London (Ford and Kynge 2017). In 2017, the UK signed the Guiding Principles of China's ambitious Belt and Road initiative. Yet, Theresa May's first in-depth trade discussions with a non-EU leader were with Indian Prime Minister Narendra Modi in 2016 (Spectator 2016), and the 2015 UK state visit of Chinese President Xi Jinping remains the high-water mark of post-2010 UK-China relations.

The FCO did most to articulate its aims and ambitions for the UK's pivot to Asia in 2012 and 2014 (FCO 2012, 2014), presenting it as multidimensional and with myriad opportunities to embrace. Yet from the beginning, it has been rife with internal contradiction. After 2010, few mechanisms of state escaped economic austerity and the drive to cut the national budget deficit, with allocations to the FCO and Ministry of Defence reduced by around 20\% (Institute for Fiscal Studies 2015). In this sense, statements on the pivot reflect existing criticisms of idealism in UK National Security Strategies: "thick with description and thin on the main question: the dialectic between the country's aims and its ability to meet them" (Porter 2010, p. 6).

Post-2010 UK activities in Asia, while intensified, delivered relatively little material commitment. New diplomatic posts in Asia came at the expense of reductions in Europe; new (bilateral and multilateral) security frameworks, agreements and dialogues brought few demands for increased hardware investment; and "golden eras" of relationships with regional partners like China were heavy on rhetoric but lighter on meaningful policy initiatives, while remaining vulnerable to diplomatic disruption. Britain, in short, advocated an unrealistic expansion of its presence and influence in Asia at a time of self-imposed resource limitations, precluding anything more than an inherently limited, partial pivot of attention and assets to the region. From these restricted and contradictory foundations, what has the UK's partial pivot achieved, and what has it done for the UK's role in Asia today?

\section{Assessing the pivot: achievements and the UK's regional role}

\section{The economic score sheet}

As we have seen, since 2010, the UK has embedded itself further into Asia's security institutions and formulated new bilateral arrangements with partners including Japan. In the absence of a more globally pronounced military-security footprint, however, its security presence in Asia is comparatively minor. To reiterate, with the emergence of 
the pivot traced to the aftermath of the financial and economic crash of $2007 / 2008$, it has always been driven primarily by economic (and diplomatic) motivations. It is in this context by which we are best placed to examine the accomplishments of the pivot to date.

Between 2010 and 2015 - the most up-to-date period for which reliable data was available at the time of writing - total UK trade (exports plus imports of goods and services) with its largest Asian trade partners typically increased, in some cases significantly. UK trade with China, for example, increased by $31 \%$ in that period, and by $12 \%$ with the ten countries of ASEAN. Yet those increases typically compare unfavourably to the preceding ("prepivot") five-year period of 2005-2010, when UK trade with China increased by more than 130\%, for example. Trade with India almost doubled between 2005 and 2010, before contracting slightly between 2010 and 2015. UK trade relations with its largest Asian partners: China, India, Japan, Hong Kong, South Korea and the ten member state collective of ASEAN, for the periods 2005-2010 and 2010-2015, appear in Table 1.

Table 1 shows a trend of UK trade increases with top Asian partners for 2005-2010 slowing (and even reversing) during 2010-2015, with the exceptions of Japan and South Korea where increases were larger in the post-2010 period. The targets set between 2010 and 2015 for doubling trade with China, Indonesia and Malaysia were missed, as trade with each in that period increased by $31 \%$ (see Table 1) and decreased by $5 \%$ and $7 \%$ respectively (calculated from ONS 2016a). For context, Table 1 also shows that in 2005-2010, UK trade changes with four of its six top Asian partners compared favourably to its overall global trade increase of 30\%. For 2010-2015 however, UK trade changes in Asia with four of its six top partners compared unfavourably to its overall global trade increase of 14\% (calculated from ONS 2017).

While UK trade with key Asian partners expanded more slowly, and even declined, during 2010-2015 compared to 2005-2010, its annual balances of payments (BoP) (total exports minus total imports) with the same partners improved. Between 2005 and 2010, the UK's BoP deficit with ASEAN for example increased by around 13\%. By 2015, that deficit had reduced by $52 \%$. The UK's BoP with its largest Asian partners are shown in Table 2.

Table 2 shows that the UK's BoP with each of its largest Asian trade partners improved (or remained static) during 2010-2015 compared with the preceding fiveyear period (calculated from ONS 2016a). Amidst an overall slowdown in total trade,

Table 1 Total UK trade with largest Asian partners, 2005-2015

\begin{tabular}{|c|c|c|c|c|c|}
\hline & \multicolumn{3}{|c|}{ UK trade (USD millions) ${ }^{\mathrm{a}}$} & \multicolumn{2}{|c|}{ UK trade change } \\
\hline & 2005 & 2010 & 2015 & $2005-2010$ & 2010-2015 \\
\hline ASEAN & 26,699 & 35,923 & 40,307 & $+35 \%$ & $+12 \%$ \\
\hline China & 24,226 & 55,898 & 73,030 & $+131 \%$ & $+31 \%$ \\
\hline India & 11,377 & 21,972 & 21,460 & $+93 \%$ & $-2 \%$ \\
\hline Japan & 24,427 & 24,015 & 26,339 & $-2 \%$ & $+10 \%$ \\
\hline Hong Kong & 15,431 & 20,371 & 21,018 & $+32 \%$ & $+3 \%$ \\
\hline South Korea & 7389 & 7792 & 13,492 & $+5 \%$ & $+73 \%$ \\
\hline Global & 945,793 & $1,225,022$ & $1,401,111$ & $+30 \%$ & $+14 \%$ \\
\hline
\end{tabular}

a All article figures presented in USD millions; conversion from GB£ millions in original ONS data calculated by July 2018 exchange rate. 
Table 2 UK BoP with largest Asian trade partners, 2005-2015

\begin{tabular}{lllllll}
\hline & \multicolumn{2}{l}{ UK BoP (USD millions) } & & \multicolumn{2}{l}{ UK BoP change } \\
\cline { 2 - 3 } \cline { 5 - 6 } & 2005 & 2010 & 2015 & & $2005-2010$ & $2010-2015$ \\
\hline ASEAN & -4278 & -4817 & -2289 & & $-13 \%$ & $+52 \%$ \\
China & $-12,258$ & $-28,679$ & $-28,025$ & & $-134 \%$ & $+2 \%$ \\
India & -305 & -4486 & -4493 & & $-1371 \%$ & $0 \%$ \\
Japan & -2508 & -3701 & 1145 & & $-48 \%$ & $*$ \\
Hong Kong & -3731 & -4182 & -331 & & $-12 \%$ & $+92 \%$ \\
South Korea & -1059 & 270 & 1939 & & $*$ & $+618 \%$ \\
Global & $-46,773$ & $-54,069$ & $-42,514$ & $-16 \%$ & $+21 \%$ \\
\hline
\end{tabular}

* Changes in BoP from negative to positive figures not shown as percentages to avoid misleading comparisons with wider data set

then, UK exports to Asia performed more strongly than regional imports during 20102015 compared to 2005-2010. However, Table 2 also shows that this was not unique to Asia and reflected a wider trend of improvement in the UK's global BoP trade profile in the post-2010 period (calculated from ONS 2017).

Complete data from 2005 on UK Foreign Direct Investment (FDI) to and from Asia is difficult to collate. However, between 2010 and 2015, annual UK FDI stocks (total direct investment) in China increased by over 40\%, from around USD 9 billion to around USD 13 billion, while Chinese FDI stocks in the UK increased by more than $400 \%$ over the same period, from around USD 480 million to around USD 2.5 billion. For the same period, UK FDI stocks in Japan increased by around 85\%, from around USD 3.5 billion to around USD 6.5 billion. Japanese FDI stocks in the UK increased by more than $75 \%$ over the period, from around USD 30 billion to around USD 53.5 billion.

Among ASEAN nations for which complete data for two-way FDI with the UK during 2010-2015 are available, a similar picture emerges. UK FDI stocks in Thailand, Malaysia and Singapore all increased strongly between 2010 and 2015. The same is true of the relationship in reverse, with the exception of Singaporean stocks in the UK which decreased overall by $73 \%$ (after strong annual increases until 2014) (calculated from ONS 2016b). UK investment into ASEAN as a whole has fallen steadily in recent years, from around USD 12 billion in 2011 to around USD 7 billion in 2015 (ASEAN 2013, 7; ASEAN 2016a, 5).

With regard to its primary aims of boosting British economic activity in Asia, then, the UK's post-2010 pivot leaves a mixed picture of slowing trade increases during 2010-2015 compared to 2005-2010, but with improvements in the UK's regional balances of payments (though only in line with the UK's global trend) and generally healthy increases in two-way FDI stocks. Overall, this has done little to improve the UK's standing as a tertiary-level trade and investment partner of Asia, behind the most prominent economies of China, the USA and Japan, and such regional and extraregional secondary partners as Singapore, Australia and the EU. Around 20\% of Vietnam's exports go to the USA, for example, and almost $30 \%$ of its imports come from China, compared with around $3 \%$ and $0.5 \%$ respectively for the UK (calculated from World Integrated Trade Solution 2018). 


\section{The UK's regional role and importance}

From a broadly unaltered position as a tertiary-level regional partner, what is the UK's importance to Asia today? The UK's post-colonial role and identity is debated. Some designate it a "great power" (Gilley and O'Neil 2014, pp. 4-5), others a "middle ranking European power" (Croft and Dorman 2014, p. 29). The intention here is not to reinforce or challenge these labels, but nonetheless speak to the "difficulties in capturing the particular position of...the UK in global affairs" (Gaskarth 2013, p. 84). To begin with, the UK's role in, and importance to, Asia (and beyond) lies not primarily with its quantities of (especially military and economic) power-as illustrated so farbut with its qualities of power. Qualities of power are understood here to be skills and specialisms utilised by international actors in the pursuit of foreign policy objectives.

This reliance on particular specialisms points to the concept of niche diplomacy (Cooper 1997). To utilise niche diplomacy means "concentrating resources in specific areas best able to generate returns worth having, rather than trying to cover the field" (former Australian Foreign Minister Gareth Evans, quoted in Cooper 1997, p.5). The concept of niche diplomacy also encourages escape from overly materialistic and somewhat limiting designations of the UK and others as "great" or "middle" powers, by highlighting the importance of, for example, persuasive actor influence and such roles as political intermediary (Henrikson 2005, p. 67). As shown below, the UK's pivot to Asia, while in many respects partial and limited in scope, has been built around core specialisms of perceived value.

First, without a comprehensive physical stature and corresponding quantities of power in Asia, the UK constitutes a regional subcontractor, employed for tasks at which it excels rather than an overall driver of Asian affairs (interview with diplomat F, London, 14 March 2016). Experience in international bureaucracy and management, for example, from leading positions in multilateral organisations, is considered an asset (interview with diplomat B, London, 16 January 2016). This is complemented by London's envisaged position as a centre of global finance (interview with diplomat B, London, 16 January 2016), with what Liu Xiaoming described as its "mature management system" (UK Embassy of China 2017). The UK's decision to join the AIIB, despite protestation from Washington, was especially well received (interview with diplomat A, London, 11 December 2015).

While the UK no longer represents a traditional military power in Asia, it is the world's second largest arms exporter. Between 2012 and 2016, India and Indonesia were its second and third largest customers (Fleurant et al. 2016), with China and Japan other significant destinations (Kift and Page 2016). The UK also boasts expertise in sub-national or "non-conventional" arenas of security. In 2016, the UK was the world's fifth largest security exporter, covering such industries as cyber and border security, policing and counter-terrorism, and infrastructure protection (Department for International Trade 2017, 4).

In this sense, the UK represents a regional (and even global) security power in Asia, from skills and competencies which facilitate its entrance to, and agency within, a security environment where it boasts an otherwise modest presence. The Asia Pacific, indeed, accounts for almost a quarter of UK security sales (Department for International Trade 2017, 15). As a leading security subcontractor, the UK secured the Defence Equipment Cooperation Framework with Japan in 2013 and integrated itself into the security and intelligence groupings detailed earlier, including the ReCAAP and the 
Shangri La Dialogue. The UK now boasts the most comprehensive regional security involvement of any non-regional actor other than the USA. As William Hague noted in 2012, "we are not a significant military power in Asia, but our...defence expertise as a nation mean that we have a role to play" (FCO 2012).

The UK's tertiary education system is another vehicle for British influence. As of 2017, more government leaders and heads of state were educated in the UK than anywhere else, including those of Malaysia, Brunei, Taiwan and Singapore (Higher Education Policy Institute 2017). British universities score well in global rankings, and the UK hosts more than $10 \%$ of the world's foreign students, second only to the USA on both measures. Six of the top ten home countries of non-EU students in the UK are Asian (HESA 2017), and interviewees indicated their governments' desires to see more Asian students granted access to Britain, more educational exchange programmes and increased funding for UK scholarships (diplomat A, London, 11 December 2015; diplomat B, London, 16 January 2016; diplomat D, London, 3 February 2016; diplomat E, London, 3 February 2016). Student visa restrictions are a point of contention in UK trade negotiations with India and Australia (Sengupta 2017; Smyth 2017), demonstrating the political weight of the globalised education industry.

Second, along with its status as subcontractor, the UK represents a facilitator for regional partners. This facilitating role begins with aiding access to Europe, since those with UK investments benefit from entry to the European Union's single market of goods, capital, services and labour. The UK government has relished its role as a "gateway to Europe for many Asian businesses" (FCO 2015), a point acknowledged by its own research (Department for International Trade 2017, 14). To global partners, Britain represents one of the more liberal, less protectionist, European trading nations, and both Asian leaders and regional diplomats affirm the perceived benefits of its gateway status (Japanese Ministry of Foreign Affairs 2016b; interviews with diplomat A, London, 11 December 2015; diplomat D, London, 3 February 2016), pointing to the UK as one of Europe's primary diplomatic and economic "hubs" (interview with diplomat D, London, 3 February 2016).

In a 2016 letter to the British and EU leaderships, the Japanese government highlighted numerous areas in which it derives benefits from Britain's EU membership, including favourable cross-border tariffs; worker mobility; the passport system for financial services; and access to EU research and development funds (Japanese Ministry of Foreign Affairs 2016b). In 2015, Xi Jinping implored Britain to use its policy influence in Europe to facilitate "an even more positive and constructive role in promoting the deepening development of China-EU ties" (quoted in Young and Blanchard 2015). London has previously touted these bridging attributes in support of its pivot: "Britain seeks to multiply our impact by working with our European partners...to drive a deeper, more comprehensive EU engagement with Asia" (FCO 2014).

Beyond Europe, Britain's facilitating role in Asia extends to a more generalised ability to expedite policy goals. The UK's entry to the AIIB for instance- - aided by its perceived competency in international organisations - prompted European neighbours to follow, enhancing the credibility and potency of the project (Ren 2016; Anderlini 2015). The UK argues Gaskarth (2013, pp. 85-86) holds an "exalted" place in international affairs by virtue of high-ranking memberships of global organisations and institutions, bringing additional gravity to this facilitating role. Japan's enhanced security coordination with Britain is driven partly by its ambition to become a permanent member of the UN Security Council, for which it requires support from existing members. As one of the five 
permanent occupants, the UK represents a useful intermediary by supporting permanent Japanese (and Indian) entry to the Council (UK Government 2015).

The UK's reputation as a "rule of law state" also means that a consistent rhetorical theme of its pivot has been the defence of the rules-based international order (FCO 2012, 2014, 2015). The durability of this "order" is of increasing interest to the Philippines, Vietnam, Taiwan and others, as they pursue UN legal rulings against China's claims in the South China Sea (BBC 2016). As among the UN's most influential members (Dee and Smith 2017), with corresponding persuasive influence (Henriksen 2005, p. 67), the UK recently made tentative commitments to protect Freedom of Navigation laws in response to China's claims (Parameswaran 2017). It is also part of the influential G7 which reinforces the claims of China's neighbours, helping to ensure the continuation of debate (G7 2017).

\section{Where next? The future of Britain's partial pivot to Asia}

In March 2017, Britain formally began the process of exiting the European Union. The long-term impacts of Brexit are unclear, but its direct effects in Asia are likely to be minimal due to the UK's relatively minor physical presence. The concern in Asia is for the prosperity and stability of the EU, which has been viewed with concern for at least the past decade; Brexit is seen as the latest in a series of European crises to jeopardise Asian interests (conversation with senior manager of British NGO in South East Asia, 4 November 2016). The EU is China's largest trade partner and a leading economic partner for all Asian economies. It accounts for around 10\% of ASEAN's international trade and is its largest external source of FDI (ASEAN 2015, 2016b).

Brexit would force a realignment of priorities in Asia, which augers a challenging future for British interests there. Little in the UK's regional trade and investment profile suggests that it could achieve a parity of interest with Brussels, or that its partial pivot of recent years better prepares it for that scenario. The EU courts the same partners as will a post-Brexit Britain and, as Japanese President Abe observed, "Japan's priority is negotiating trade deals with Europe...rather than individual states in Europe" (Prime Minister's Office 2016). Indonesia's former Trade Minister noted that the UK would be required "to offer better terms to Indonesia than the [European Union]...Indonesia will have to make more concessions for a big trophy like the EU" (Asia House 2016).

Key elements of the UK's qualities of power, which have driven its post-2010 pivot to Asia, could be sustained. British specialisms in international bureaucracy, security and education, for instance, operate largely independently of Brussels (though as already noted, post-Brexit student visas are already a point of debate). Those elements constitutive of its status as specialist subcontractor therefore could, for the most part, endure. Equally however, exiting the Union would render more vulnerable the UK's status as regional facilitator, particularly its prized functions as economic gateway and political bridge to Europe.

Asian economies and investors with UK operations fear reduced access to EU markets (Posaner 2017). In its letter to London and Brussels, Tokyo repeatedly stressed the value of British connections to Europe, including tariff-free movements of goods, services, data and cross-border investment; "Japanese businesses...have invested actively to the UK, which was seen to be a gateway to Europe...we strongly request that the UK will consider this fact seriously" (Japanese Ministry of Foreign Affairs 2016b). 
It also identifies the importance to Japan of British-based EU agencies, notably the European Medicines Agency, which is expected to move to Amsterdam in 2019.

Interviewees for this study confirmed that Asia would lose the influence of a liberal trading "champion" in Europe (diplomat B, London, 16 January 2016) and a leading proponent of "free trade and the multilateral trading system" (diplomat C, London, 20 January 2016). For these reasons, "it would be much better for your sake and for our sake that you remained within the EU" (interview with diplomat D, London, 3 February 2016). With the UK's facilitating role in Asia extending to politics and diplomacy, it is expected that its "voice on other issues, on security etc., would [also] be lost" (interview with diplomat C, London, 20 January 2016).

Asian governments lament the prospect of an EU without Britain partly because the direction of travel in Europe has been towards more centralised and institutional-level arrangements to which Asian economies are attracted; the EU recently finalised a comprehensive trade deal with Japan and negotiates with China, India, ASEAN and others (European Commission 2018). Repeated statements of the anticipated "loss" of Britain point to a future in which a "trophy" EU remains the priority in Asia. A key post-Brexit challenge for London would be to convince Asian partners already sceptical of Britain's ability to occupy a significant long-term regional presence that potential losses such as of its gateway status to Europe can be successfully compensated for.

Finally, Britain's post-Brexit role in Asian affairs is risked via alienation within multilateral settings. As already described, regional partners like Japan court the UK's elevated position in the United Nations, and with political factions central to twentyfirst century multilateralism, that position has been bolstered and amplified by communal EU membership (Dee and Smith 2017). A rhetorical theme of Britain's pivot to Asia has been a commitment to the rules-based international order (FCO 2012, 2014, 2015), with London marketing itself as a networked, bridging facilitator to this end; "when the United States is shifting its focus towards the region and we wish to see the European Union take a more active role, there is a great deal for us to work on with them", noted William Hague (FCO 2012). Indeed, it has been argued that London represents a Transatlantic "interlocutor" between Brussels and Washington (Stokes and Whitman 2013, p. 1103). Yet, in the post-2016 eras of Brexit and Donald Trump, clear uncertainties and tensions have emerged both in the UK's present and future relations with Europe (Hix 2018) and with the USA (Stacey 2017). Marginalisation in any multilateral setting would almost inevitably limit the projection of British influence and test perceptions in Asia of the UK as a partner of global standing.

\section{Conclusion}

In 2012, William Hague argued: "We want Britain to be a leading partner [in Asia] ...in trade and commerce, in culture, education and development, and in foreign policy and security" (FCO 2012). However, what has been termed here the UK's "pivot" to Asia, emerging from 2007/2008 and intensifying in the post-2010 period, has done little to improve its position as a tertiary-level partner of Asia. Trade growth with China, India, ASEAN and others slowed between 2010 and 2015 compared to the preceding ("pre-pivot") five-year period and compared unfavourably to the UK's wider global trade patterns (though foreign direct investments remained strong). Its military-security presence in Asia also remains limited. 
As such, the UK's regional importance, and, indeed, its contemporary global identity, is best explained not in terms of its quantities of power - as a "great power", a "middle power" or otherwise - but by its qualities of power, as a subcontractor of valued skills and specialisms, and as a networked facilitator of international policy goals. The UK concentrates its resources in Asia in niche areas such as finance, education and security sales where it is best equipped to generate returns, and where it is unable to "cover the field" with its quantities of military and economic power, especially at a time of fiscal restrictions and selfimposed limitations on foreign policy resources.

Indeed, the UK's unrealised ambitions for substantial and consistent increases in trade and investment across Asia, and of a reinvigorated political and security presence, leave its attempted pivot partial and disjointed. While confidently and romantically articulated by successive Foreign Secretaries as a strategy to reinvigorate Britain's place in Asia, domestic austerity measures have essentially prevented that dream from materialising. As Porter (2010, p. 6) explains, the UK “doesn't do strategy coherently", and the UK's modern-day pivot to Asia has been reactionary and impulsive rather than the product of long-term strategic frameworks and planning.

The historically "ad hoc and patchy" nature of UK foreign policy, Hague once lamented, brought the complaint "that British Ministers only get in touch when a crisis arises" (FCO 2010). Yet, the official narrative of the UK's pivot to Asia has extended little beyond the need to seize opportunities in Asia after economic and financial crises at home. The perception that Britain's interests are increasingly contingent on the flow of potential profit was expressed in an interview for this research: "Britain takes a more cautious approach than before. If it is too costly then you don't take the risk" (diplomat A, London, 11 December 2015).

With the politics of Brexit playing out in Asia, a new fog of uncertainty surrounds its policy aims. London and Brussels are stakeholders among many in the Brexit negotiations, and a failure to defend the interests of others will live long in the memory. Tokyo's cautionary letter to London and Brussels illustrates this point, and Britain position must speak to their concerns with displays of cooperation and compromise, and a long-term relationship with Europe which accommodates the interests of global others. In doing so, the UK can help preserve a relationship with Brussels which protects its coveted international facilitator status.

Across its range of foreign and diplomatic services, the UK arguably boasts Europe's strongest networks and expertise in Asia. A suspicion among local partners, however, is that they may become subsumed by negotiations with Europe even beyond its planned EU exit in March 2019 (conversation with senior manager of British NGO in South East Asia, 4 November 2016), causing it to "pivot" away from the region again. Indeed, signals emerged in late 2017 that the FCO's stated network shift to Asia would formally be abandoned, with plans for "redressing the [diplomatic] balance" back towards Europe in the service of Brexit (Elliott 2017). The UK must accept that the quantities of (economic and military) power its pivot has been primarily designed to enhance will never sufficiently define Britain's place in Asia, and that the qualities of power on which its regional presence most fundamentally rely are inextricable from its traditional role as a specialised and globally interconnected, European, partner.

Acknowledgements I am extremely grateful to the interviewees who spared time and effort to contribute to this research. I also thank colleagues of the Swedish Institute of International Affairs and the University of Edinburgh who gave valuable comments on earlier drafts. Finally, I thank the anonymous article reviewers for their time and carefully considered suggestions for revision. 
Open Access This article is distributed under the terms of the Creative Commons Attribution 4.0 International License (http://creativecommons.org/licenses/by/4.0/), which permits unrestricted use, distribution, and reproduction in any medium, provided you give appropriate credit to the original author(s) and the source, provide a link to the Creative Commons license, and indicate if changes were made.

\section{References}

Anderlini J (2015) UK move to join China-led Bank a surprise even to Beijing. Financial Times. https://www. ft.com/content/d33fed8a-d3a1-11e4-a9d3-00144feab7de?mhq5j=e1. Accessed 8 Dec 2017

ASEAN (2013) ASEAN investment report 2012: the changing FDI landscape. ASEAN Secretariat, Jakarta

ASEAN (2015) ASEAN trade by partner countries/regions, 2015. http://asean.org/storage/2016/11/Table24_ as-of-6-dec-2016.pdf. Accessed 2 Dec 2017

ASEAN (2016a) ASEAN investment report 2016: foreign direct investment and MSME linkages. ASEAN Secretariat, Jakarta

ASEAN (2016b) Top ten sources of foreign direct investment inflows in ASEAN. http://asean. org/storage/2015/09/Table-27_oct2016.pdf. Accessed 20 Nov 2017

Asia House (2016) Indonesia to use EU template for post-Brexit UK FTA, says Jokowi advisor. http://asiahouse.org/indonesia-use-eu-template-post-brexit-uk-fta-says-jokowi-advisor/. Accessed 8 Dec 2017

BBC (2016) South China Sea: tribunal backs case against China brought by Philippines. http://www.bbc.co. uk/news/world-asia-china-36771749. Accessed 11 Nov 2017

Bisley N, Phillips A (2013) A rebalance to where?: US strategic geography in Asia. Survival 55(5):95-114

Blount C (2013) Staying in step: the US “pivot" and UK strategic choices. Strateg Stud Q 7(2):137-150

Cabinet Office (2012a) PM speech in Indonesia. https://www.gov.uk/government/speeches/transcript-pmspeechin-indonesia. Accessed 18 Nov 2017

Cabinet Office (2012b) David Cameron with the Prime Minister of Malaysia. https://www.gov. uk/government/speeches/david-cameron-with-the-prime-minister-of-malaysia. Accessed 20 Dec 2017

Casarini N (2015) China's inroads into the West. World Today 71(5):14-16

Cooper A (1997) Niche diplomacy: middle powers after the Cold War. MacMillan, London

Confucius Institute Headquarters (2014) About Confucius institutes, http://english.hanban.org/node_10971. htm. Accessed 4 July 2018

Higher Education Policy Institute (2017) UK is (just) number 1 for educating the world's leaders. http://www. hepi.ac.uk/2017/08/05/uk-just-number-1-educating-worlds-leaders/. Accessed 3 Nov 2017

Dee M, Smith K (2017) UK diplomacy at the UN after Brexit: challenges and opportunities. Br J Polit Int Rel 19(3):527-542

Department for Business, Innovation and Skills (2012) Summit boosts UK-China trade and Investment. https://www.gov.uk/government/news/summit-boosts-uk-china-trade-and-investment-foreign-secretary. Accessed 29 Oct 2017

Department for International Trade (2017) UK Defence and Security Export Statistics for 2016. https://www. gov.uk/government/uploads/system/uploads/attachment_data/file/631343/UK_defence_and_security_ export_statistics_2016. Accessed 8 Nov 2017

Department for International Trade (2016) UK-China Infrastructure Academy opens its doors and welcomes first students. https:/www.gov.uk/government/news/uk-china-infrastructure-academy-opens-its-doorsand-welcomesfirst-students. Accessed 4 July 2018

Elliott F (2017) Asian embassies cut by Boris Johnson to fund EU diplomats. The Times. https://www. thetimes.co.uk/article/asian-embassies-cut-by-boris-johnson-to-fund-eu-diplomats-g172m0gh7 ?shareToken=7d88e9d4536a8c06a9caf867d6d9b644. Accessed 4 Jan 2017

Embassy of France in London (2013) Laurent Fabius focuses on French ties with Asia https://uk.ambafrance. org/Laurent-Fabius-focuses-on-French. Accessed 8 Nov 2017

European Commission 2018 (2018) Negotiations and agreements. http://ec.europa.eu/trade/policy/countriesandregions/negotiations-and-agreements/. Accessed 14 July 2018

Fleurant A, Wezeman P, Wezeman S, Tian N (2016) Trends in international arms transfers. SIPRI. https://www.sipri.org/sites/default/files/Trends-in-international-arms-transfers-2016.pdf. Accessed 1 Dec 2017

Ford J, Kynge J (2017) Beijing signals end of China-UK "golden age". Financial Times. https://www.ft. com/content/4ab22b66-d42d-11e6-9341-7393bb2e1b51. Accessed 1 Nov 2017 
FCO (2010) Britain's foreign policy in a networked world. https:/www.gov.uk/government/speeches/britainsforeign-policy-in-a-networked-world\%2D\%2D2. Accessed 2 Nov 2017

FCO (2011) Foreign Secretary: "for the first time in decades our diplomatic reach will be extended not reduced". https://www.gov.uk/government/news/foreign-secretary-for-the-first-time-in-decades-ourdiplomatic-reach-will-beextended-not-reduced. Accessed 5 Nov 2017

FCO (2012) Britain in Asia. https://www.gov.uk/government/speeches/britain-in-asia. Accessed 4 Oct 2017

FCO (2014) The UK in the Asian century. https://www.gov.uk/government/speeches/the-uk-in-the-asiancentury. Accessed 5 Nov 2017

FCO (2015) Foreign Secretary's speech on the UK in Asia Pacific. https://www.gov. uk/government/speeches/foreign-secretarys-speech-on-the-uk-in-asia-pacific. Accessed 17 Oct 2017

Foreign Affairs Committee (2009) Foreign and Commonwealth Office Annual Report 2007-08: second report of the session 2008-09. Stationary Office, London

G7 (2017) Joint Communiqué: G7 Foreign Ministers Meeting. http://www.g8.utoronto.ca/foreign/170411communique.html. Accessed 12 Nov 2017

Gaskarth J (2013) British foreign policy. Polity Press, Cambridge

Gilley O’N (2014) Middle powers and the rise of China. Georgetown University Press, Washington DC

Henriksen A (2005) Niche diplomacy in the world public arena: the global 'corners' of Canada and Norway. In: Melissen J (ed) The new public diplomacy: soft power in international relations. Palgrave, London, pp 67-87

HESA (2017) Higher education student enrolments and qualifications obtained at higher education providers in the United Kingdom 2015/16. https:/www.hesa.ac.uk/news/12-01-2017/sfr242-studentenrolmentsand-qualifications. Accessed 1 Nov 2017

Hix S (2018) Brexit: where is the EU-UK relationship heading? JCMS, online first 12 July. doi:https://doi. org/10.1111/jcms.12766. Accessed 10 July 2018

HM Treasury (2010) Speech by the Chancellor of the Exchequer. https://www.gov. uk/government/speeches/speech-by-the-chancellor-of-the-exchequer-rt-hon-george-osbornemp-at-thequeens-speech-economy-debate. Accessed 14 Oct 2017

HM Treasury (2015) Chancellor: let's create a golden decade for the UK-China relationship. https://www.gov. uk/government/speeches/chancellor-lets-create-a-golden-decade-for-the-uk-china-relationship. Accessed 1 Nov 2017

House of Commons Defence Committee (2011) The strategic defence and security review and the national security strategy: sixth report of session 2010-12, vol 1. Stationary Office, London

Japanese Ministry of Foreign Affairs (2016a) Second Japan-UK foreign and defence ministers' meeting (" $2+$ 2"). http://www.mofa.go.jp/press/release/press4e_001000.html. Accessed 10 Nov 2017

Japanese Ministry of Foreign Affairs (2016b) Japan's message to the United Kingdom and the European Union. http://www.mofa.go.jp/files/000185466.pdf. Accessed 12 Dec 2017

Jennings P (2013) The US rebalance to the Asia Pacific: an Australian perspective. Asia Policy 15:38-44

Kift R, Page R (2016) Arms industry statistics. House of Commons Library Briefing Paper CBP 7842

Netherlands Government (2016) Speech by Minister Koenders in Jakarta. https://www.government. nl/documents/speeches/2016/03/24/speech-koenders-in-jakarta. Accessed 1 Nov 2017

ONS (2016a) Annual UK trade exports and imports by country 1999 to 2015. https://www.ons.gov. $\mathrm{uk} / \mathrm{economy/nationalaccounts/balanceofpayments/adhocs/006034}$ annualuktradeexportsandimportsbycountry1999to2015. Accessed 17 Dec 2017

ONS (2016b) Inward and outward foreign direct investment for ASEAN countries, China and Japan for earnings, flows and positions, 2007 to 2015. https:/www.ons.gov.uk/economy/nationalaccounts/balanceofpayments/ adhocs/006924inwardandoutwardforeigndirectinvestmentforaseancountrieschinaandjapanforearningsflows andpositions2007to2015. Accessed 17 Dec 2017

ONS (2017) The pink book: 2017. https://www.ons.gov.uk/economy/nationalaccounts/balanceof payments/datasets/9geographicalbreakdownofthecurrentaccountthepinkbook2016. Accessed 14 June 2018

Osborn A (2013) Britain's Cameron ‘turns page’ on Dalai Lama row with China visit. Reuters. https:/www. reuters.com/article/us-britain-china-cameron/britains-cameron-turns-page-on-dalai-lama-row-withchinavisit-idUSBRE9AT05I20131130. Accessed 7 Nov 2017

Pamment J (2014) Putting the GREAT back into Britain: national identity, public-private collaboration and transfers of brand equity in 2012's global promotional campaign. Br J Polit Int Rel 17(2):260-283

Parameswaran P (2017) A more muscular Britain in the South China Sea? The Diplomat. https://thediplomat. com/2017/08/a-more-muscular-britain-in-the-south-china-sea/. Accessed 24 Oct 2017

Porter P (2010) Why Britain doesn't do grand strategy. RUSI J 155(4):6-12

Posaner J (2017) Nissan to review UK investment decision based on Brexit deal: CEO. Politico. http://www. politico.eu/article/nissan-to-review-uk-investment-decision-based-on-brexit-deal-ceo/. Accessed 12 Nov 2017 
Prime Minister's Office (2015) PM sets sights on South-east Asia. 27 July. https://www.gov. uk/government/news/pm-sets-sights-on-south-east-asia-with-750m-business-deals-and-new-eutrade-deal. Accessed 12 July 2018

Prime Minister's Office (2016) PM statement at press conference with Japanese Prime Minister Abe. 5 May. https:/www.gov.uk/government/speeches/pm-statement-at-press-conference-with-japanese-primeminister-abe-5-may-2016. Accessed 24 Nov 2017

Prime Minister's Office (2017) The government's negotiating objectives for exiting the EU. 17 January. https://www.gov.uk/government/speeches/the-governments-negotiating-objectives-for-exiting-the-eu-pmspeech. Accessed 8 Nov 2017

Ren X (2016) China as an institution builder: the case of the AIIB. Pac Rev 29(3):435-442

Sengupta K (2017) UK post-Brexit trade deal with India threatened by Theresa May's visa crackdown. Independent. http://www.independent.co.uk/news/uk/politics/brexit-uk-britain-india-trade-deal-freedomofmovement-delhi-boris-johnson-a7534026.html. Accessed 28 Oct 2017

Sharief F (2013) European pivots to southeast Asia: leaving the EU-Asian corridors? Center for Strategic and International Studies. https://www.cogitasia.com/european-pivots-to-southeast-asia-leaving-the-euaseancorridors/. Accessed 23 Nov 2017

Simón L, Klose S (2016) European perspectives towards the rise of Asia: contextualising the debate. Asia Europe Journal 14(3):239-260

Smyth J (2017) Australia warns UK not to toughen visa regime. Financial Times. https://www.ft. com/content/58fdabbc-7047-11e7-aca6-c6bd07df1a3c. Accessed 2 Dec 2017

Spectator (2016) Theresa May's passage to India. 5 November. https://www.spectator.co.uk/2016/11/mrsmaystrade-visit-to-india-sends-all-the-right-signals/. Accessed 18 July 2018

Stacey J (2017) The hollowing out of the special relationship. Foreign Aff. 5 September https://www. foreignaffairs.com/articles/2017-09-05/hollowing-out-special-relationship. Accessed 20 July 2018

Stokes D, Whitman RG (2013) Transatlantic triage? European and UK grand strategy after the US rebalance to Asia. Int Aff 89(5):1087-1107

Sverdrup-Thygeson B (2017) The bear and the EU-China-US triangle: transatlantic and Russian influences on EU's pivot to Asia. Asia Europe Journal 15(2):161-172

Tow W, Stewart D (eds) (2015) The new US strategy towards Asia. Routledge, London

Turner O (2014) American Images of China: Identity, Power, Policy. Routledge, London

UK Embassy of China (2017a) "China: Navigate the New Silk Road" Investor Roadshow. http://www. chineseembassy.org.uk/eng/tpxw/t1470544.htm. Accessed 11 Dec 2017

UK Embassy of China (2017b) "China: Navigate the New Silk Road" Investor Roadshow. http://www. chineseembassy.org.uk/eng/tpxw/t1470544.htm. Accessed 11 Dec 2017

UK Government (2010) A strong Britain in an age of uncertainty: the national security strategy. Stationary Office, London

UK Government (2012) Foreign Secretary announces the UK is to open two new diplomatic posts in India. 16 May. https:/www.gov.uk/government/news/foreign-secretary-announces-the-uk-is-to-open-two-newdiplomatic-postsin-india. Accessed 9 July 2018

UK Government (2013) Foreign secretary signs groundbreaking defence and security agreements with Japan. 4 July. https:/www.gov.uk/government/news/foreign-secretary-signs-groundbreaking-defence-andsecurityagreements-with-japan. Accessed 13 July 2018

UK Government (2014) UK and Republic of Korea hold first strategic talks in London. 4 December. https:/www.gov.uk/government/news/uk-and-republic-of-korea-hold-first-strategic-talks-in-london. Accessed 8 July 2018

UK Government (2015) National security strategy and strategic defence and security review: a secure and prosperous United Kingdom. Stationary Office, London

UK Government (2016) China-UK high-level security dialogue: official statement. 13 June. https://www.gov. uk/government/publications/china-uk-high-level-security-dialogue-official-statement. Accessed 16 July 2018

Vasager J (2016) Britain revives military engagements east of Suez. Financial Times. https://www.ft. com/content/3477fe5a-c809-11e6-8f29-9445cac8966f?mhq5j=e1. Accessed 8 Nov 2017

Warren D (2014) Does Britain matter in East Asia? Chatham House, London

Wintour P (2011) China rebukes Cameron for pointing the finger over human rights abuses. Guardian. https://www. theguardian.com/world/2011/jun/27/china-cameron-human-rights-abuses. Accessed 23 Nov 2017

World Integrated Trade Solution (2018) World Integrated Trade Solution. http://wits.worldbank.org/. Accessed 12 Dec 2017 
Young S, Blanchard B (2015) China hopes to see a united EU, Xi tells Britain on visit. Reuters. http://uk. reuters.com/article/uk-china-britain-eu-idUKKCN0SH0AG20151023. Accessed 3 Nov 2017 